\title{
ADAPTASI BIOMOLEKULER HIPERTROPI JARINGAN OTOT RANGKA PADA LATIHAN BEBAN DAN MANFAATNYA PADA SINDROMA METABOLIK
}

\author{
I Putu Adiartha Griadhi \\ Bagian Ilmu Faal Fakultas Kedokteran Universitas Udayana \\ E-Mail : adiarthagriadhi@gmail.com
}

\begin{abstract}
ABSTRAK
Latihan beban adalah salah satu latihan yang diperlukan untuk dapat mencapai kebugaran fisik. Latihan ini dapat meningkatkan masa otot dan fungsi metabolik otot sehingga menjadi latihan yang penting pada kondisi sindrom metabolik. Otot adalah jaringan sensitif hormon insulin terbesar pada tubuh manusia, jaringan ini mengkonsumsi banyak oksigen dan mengkonsumsi sebagian besar glukosa melalui perantaraan insulin. Latihan beban mengakibatkan hipertropi atau penambahan masa otot dan hiperplasia atau pertambahan jumlah sel otot. Berbagai mekanisme biomolekuler dapat menjelaskan proses hipertropi dan hiperplasia tersebut diantaranya jalur anabolik mTOR, jalur katabolik myostatin - Smad dan jalur repair oleh Sel Satelit. Pemahaman terhadap proses biomolekuler ini dapat memberikan landasan teoritis dalam menyusun program latihan beban sehingga latihan menjadi efektif dan aman.
\end{abstract}

Kata kunci : latihan beban, sindrom metabolik, hipertropi otot

BIOMOLECULAR ADAPTATION OF SKELETAL MUSCLE TISSUE HYPERTROPHY IN WEIGHT TRAINING AND ITS BENEFITS IN METABOLIC SYNDROME

\begin{abstract}
Weight training is one of the exercises needed to achieve physical fitness. This exercise can increase muscle mass and metabolic function of the muscles so that it becomes an important exercise in the condition of the metabolic syndrome. Muscle is the largest hormone-sensitive tissue in the human body, this tissue consumes a lot of oxygen and consumes most of the glucose through the mediation of insulin. Weight training results in hypertrophy or increase in muscle mass and hyperplasia or increase in the number of muscle cells. Various biomolecular mechanisms can explain the hypertrophy and hyperplasia processes including the anabolic mTOR pathway, the catabolic pathway myostatin - Smad and the repair pathway by Satellite Cells. Understanding of the biomolecular process can provide a theoretical foundation in developing a weight training program so that the exercise becomes effective and safe.
\end{abstract}

Keyword : weight training, metabolic syndrom, muscle hipertrophy 


\section{Pendahuluan}

Aktivitas fisik yang direkomendasikan untuk usia dewasa terdiri dari latihan kebugaran erobik, latihan kekuatan dan fleksibilitas otot serta latihan untuk mencapai komposisi tubuh yang baik. Rekomendasi ini menunjukkan bahwa latihan kebugaran erobik saja tidaklah cukup untuk mencapai kebugaran, harus disertai dengan latihan kekuatan dan fleksibilitas otot. Dengan demikian, latihan otot harus diperkenalkan seacra luas untuk menunjang latihan kebugaran kardiovaskuler yang telah terbukti bermanfaat dalam mencegah berbagai macam penyakit kronis.

Latihan kekuatan otot adalah latihan pembebanan untuk meningkatkan kekuatan otot melalui mekanisme hipertropi dan hiperplasia otot. Latihan otot dilakukan dengan frekuensi, intensitas dan durasi atau repetisi tertentu. Latihan dengan beban berat dan durasi yang pendek memberikan adaptasi berupa peningkatan kekuatan otot (muscle strength) sedangkan latihan dengan beban sedang dan durasi yang panjang akan meningkatkan daya tahan otot (muscle endurance).

Adaptasi otot akibat latihan dapat dijelaskan dengan prinsip general adaptation syndrom (GAS) oleh Han's Selye yang dikembangkan menjadi prinsip superkompensasi. Model superkompensasi menjelaskan adaptasi kekuatan dan daya tahan otot sebagai fungsi waktu, menjelaskan bagaimana adaptasi terjadi kekuatan atau daya tahan otot pada rentang waktu tertentu. Namun demikian, prinsip ini belum menjelaskan tentang mekanisme molekuler adaptasi yang terjadi pada otot.

Perkembangan ilmu biomedik saat ini telah dapat menjelaskan adaptasi tubuh yang terjadi setelah latihan. Model ini dikenal dengan nama signal transduction model atau model transduksi sinyal. Dijelaskan bahwa latihan fisik akan mengakibatkan perubahanperubahan molekuler yang dikenal oleh tubuh sebagai sebuah sinyal latihan. Sinyal latihan ini dihantarkan melalui berbagai rantai protein untuk ke pusat integrasi untuk menentukan jenis respon yang tepat. Respon ini kemudian dihantarkan ke inti sel atau organela lain untuk mengatur transkripsi genetik atau produksi protein sebagai bentuk respon terhadap sinyal latihan.

\section{Adaptasi Otot dapat Meningkatkan Fungsi Metabolik}

Sindroma metabolik sangat dikenal di bidang kedokteran. Sindroma ini ditandai dengan peningkatan tekanan darah, intoleransi glukosa, hipertrigliserida, rendahnya HDL dan obesitas visceral. Permasalahan pokok pada kondisi tersebut adalah penurunan sensitivitas jaringan terhadap insulin dan penurunan kemampuan menggunakan substrat selama metabolisme (metabolic inflexibility). Jaringan yang memiliki peranan penting pada sindroma ini adalah jaringan otot. Otot adalah jaringan sensitif insulin terbesar pada tubuh manusia $(40-50 \%$ berat badan), jaringan otot mengkonsumsi oksigen cukup banyak $(20-30 \%)$ saat istirahat. Otot juga menggunakan sebagian besar glukosa $(75-95 \%)$ yang diperantarai oleh hormon insulin.

Menjaga sensitivitas otot terhadap insulin adalah usaha mendasar untuk mencapai fleksibilitas metabolik ${ }^{(1)}$. Pada individu yang sehat secara metabolik, akan dijumpai fleksibilitas metabolisme yang tinggi dalam penggunaan lipid dan karbohidrat sebagai sumber energi. Sedangkan, pada seseorang yang menderita sindrom metabolik akan dijumpai infleksibilitas dalam transisi penggunaan lipid dan karbohidrat sebagai sumber energi. Infleksibilitas ini diakibatkan karena adanya resistensi insulin pada jaringan otot. 
Resistensi insulin ini terjadi akibat gangguan pada fungsi mitokondria, peningkatan lipid intramuskuler, Reactive Oxygen Substrate (ROS), serta pergeseran profil adiponektin menjadi pro inflamasi ${ }^{(1)}$. Produksi ROS yang lebih besar dari kemampuan tubuh untuk mengatasinya mengakibatkan terjadinya stress oksidatif. Stress oksidatif mengakibatkan kerusakan pada mitokondria. Bahan makanan yang mengandung lipid berlebih dapat menginduksi terjadinya stress oksidatif, demikian pula peningkatan kadar glukosa secara akut dan kronis dapat pula meningkatkan stress oksidatif yang pada akhirnya akan berakhir pada resistensi insulin. Penumpukan lemak intramuskular terjadi akibat gangguan pada kemampuan oksidasi lemak oleh otot ${ }^{(2)}$.

Berdasarkan uraian tersebut di atas, setiap perubahan jumlah masa otot, kecepatan metabolismenya, dan atau perubahan responnya terhadap hormon dan faktor sistemik lainnya akan mempengaruhi metabolisme tubuh secara signifikan. Faktor yang berhubungan erat dengan perubahan pada otot adalah tingkat aktivitas fisik seseorang. Individu dengan kebugaran kardiorespirasi dan kekuatan otot yang buruk memiliki risiko menderita sindroma metabolik. Latihan fisik yang adekuat dan berat badan yang sehat adalah hal mendasar untuk mengurangi risiko sindrom metabolik (1).

Penelitian menunjukkan bahwa kombinasi latihan otot dengan latihan erobik dapat meningkatkan fungsi metabolik tubuh. Kombinasi latihan erobik dan latihan otot akan meningkatkan sensitivitas insulin, fungsi sel Beta (indeks disposisi) dan efektivitas pemakaian glukosa. Perbaikan sensitifitas insulin dapat bertahan hingga 14 hari setelah latihan terakhir. Model olahraga yang baik adalah latihan otot 3 kali seminggu disertai dengan latihan erobik setara intensitas sedang.
Kombinasi latihan erobik dan latihan otot cukup baik untuk meningkatan profil lipid, sensitivitas insulin dan konsentrasi adiponektin yang bermakna dibandingkan dengan kelompok kontrol, atau kelompok dengan latihan erobik atau latihan otot saja. Kelompok erobik menunjukkan penurunan masa otot setelah latihan yang disertai dengan peningkatan kemampuan tubuh dalam melakukan oksidasi protein. Hal ini berakibat pada penurunan tingkat metabolisme seseorang setelah latihan erobik. Hanya latihan kombinasi dengan periodisasi linear saja yang dapat mempertahankan masa otot sekaligus mempertahankan tingkat metabolisme seseorang. Dengan demikian, model latihan kombinasi antara latihan erobik dan otot lebih efektif dalam memperbaiki profil lipid dan sensitivitaas insulin.

Pada penelitian lain dengan subyek remaja usia 14 - 18 tahun yang mengalami obesitas diperoleh bahwa kombinasi latihan erobik dengan latihan otot selama 22 minggu diperoleh hasil penurunan lemak abdomen, penurunan jumlah Apo B dan rasio Apo B/Apo A-1. Namun tidak dijumpai adanya perubahan Apo A-1, VAT, dan HSCRP pada peneltiian ini.

Penelitian lain yang serupa pada kelompok umur yang sama juga menunjukkan adanya penurunan persentase lemak tubuh sebesar 1,1\% pada erobik dan 1,6\% pada latihan otot saja. Pada latihan kombinasi dijumpai penurunan sebesar 1,4 \% yang bermakna. Penurunan lingkar perut terjadi paling besar pada kelompok latihan kombinasi dibandingkan dengan latihan erobik saja atau otot saja.

\section{Hipertropi sebagai Hasil Latihan Otot}

Latihan beban akan mengaktifkan jalur transduksi sinyal yang mengatur sintesis protein otot, degradasi protein, transkripsi dan perilaku sel satelit. Jalur transduksi ini mengubah gerakan mekanik yang dilakukan 
saat latihan menjadi sinyal kimiawi yang mampu menginduksi respon pertumbuhan otot terutama melalui sintesis protein. Penelitian menunjukkan bahwa jalur mTOR adalah titik pusat dimana otot akan mengintegrasikan input dari berbagai sumber dan menentukan derajat sintesis protein dan hipertropi otot yang terjadi. Jalur yang berlawanan dengan mTOR dan pertumbuhan otot adalah jalur myostatin - Smad. Defek genetik akan menekan jalur ini yang berakibat besar pada ukuran otot.

Prinsip pembebanan (overload) menyatakan bahwa adaptasi peningkatan kekuatan otot hanya dapat dicapai dengan latihan yang sistematik, progresif dengan frekuensi, intensitas dan dilakukan dalam durasi yang cukup untuk adaptasi. Sehingga, rencana suatu latihan otot harus jelas yang terdiri dari berat beban (\%1RM), volume latihan (set dan repetisi), waktu istirahat secara progresif periode latihan. Selain itu, kita nyatakan pula tujuan latihan (kekuatan, daya tahan, hipertropi), jenis latihan yang dilakukan, dan sifat kontraksi yang dilatih (eksentrik, konsentrik, isometrik, kecepatan kontraksi) (3).

Walaupun program latihan telah dibuat dengan baik, adaptasi masa otot dan kekuatannya sangat bervariasi diantara individu. Penelitian oleh Hubal (2005) menunjukkan bahwa adanya perbedaan respon individu terhadap latihan. Pada penelitian ini juga ditemukan bahwa tidak ada hubungan yang erat antara ukuran otot dengan kekuatannya.

Kekuatan otot yang meningkat pada awal periode latihan terjadi sebagai akibat peningkatan aktivasi neorumuskuler.
Hipertropi otot akan meningkat pada tahapan berikutnya ${ }^{(4)}$. Secara spesifik, ditunjukkan bahwa $^{(5)}$ adaptasi neurologis pada tahap awal latihan juga disertai dengan peningkatan sintesis protein. Proses rekrutmen unit motorik mengakibatkan sinkronisasi kontraksi otot yang dapat membuat otot terlihat lebih kuat walaupun hipertropi belum terjadi (Kim et al., 2005).

Ukuran otot dapat bertambah melalui mekanisme hipertropi yaitu penambahan ukuran dan masa sel. Hipertropi dapat terjadi apabila tubuh berada dalam keseimbangan protein positif, sintesis protein lebih besar dibandingkan pemecahannya. Penelitian menunjukkan bahwa peningkatkan sintesis protein pada otot terjadi hingga 72 jam setelah latihan. Masa sintesis protein ini dapat memanjang apabila seseorang berada pada kondisi sesudah makan ${ }^{(6)}$. Pada Gambar 1 dapat dilihat bahwa latihan yang dilakukan pada kondisi puasa (fasting) justru mengakibatkan terjadinya degradasi protein, mengakibatkan keseimbangan metabolisme protein menjadi negatif yang berarti menghambat proses hipertropi otot (7). Setelah makan keseimbangan protein positif karena adanya asupan asam amino dari makanan. Sedangkan pada kondisi puasa tubuh melakukan pemecahan protein untuk menyediakan asam amino esensial untuk hipertropi otot ${ }^{(8) .}$

\section{Adaptasi Molekuler yang Terjadi pada Latihan Beban}

\section{A. Jalur Anabolik mTOR}

Mekanisme adaptasi molekuler yang terjadi pada latihan beban adalah 1) jalur anabolik mTOR, 2) jalur katabolik myostatin-Smad, dan 3) jalur repair oleh sel satelit. 

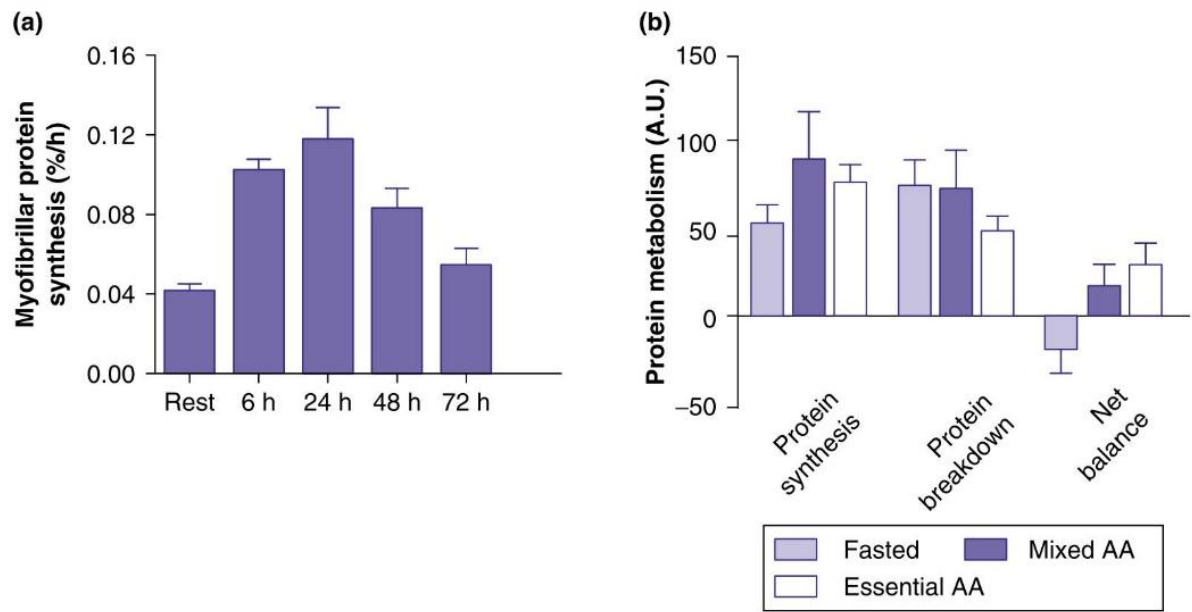

Gambar 1: Wackerhage 2014 - Molecul (3)

Mammalian target of rapamycin (mTOR) adalah serine/threonin kinase yang dapat meningkatkan proses sintesis protein (translasi mRNA menjadi protein di Riobosom) dan biogenesis ribosom (kapasitas sel dalam memproduksi protein) serta pada beberapa sel menghambat autofagi. Selain itu mTOR juga dapat meningkatkan pembelahan sel dan transkripsi beberapa gen. Penelitian awal oleh Baar dan Esser (1999) menunjukkan bahwa hipertropi otot berkaitan langsung dengan gen S6KI yang merupakan target dari mTOR. Bodine (2001) menunjukkan bahwa pemberian rapamycin dapat menghambat hipertropi otot pada tikus yang dilatih beban. Drummond (2009) menemukan hal yang kondisi tersebut dapat terjadi pada manusia. Penelitian Goodman (2011) pada tikus dengan mutasi mTOR atau resisten terhadap rapamycin menemukan adanya hipertropi otot walaupun tikus tersebut diberikan rapamycin.

Kompleks protein mTOR tersusun dari dua jenis komplek protein yaitu mTORC1 dan mTORC2. Kedua bentuk ini berbeda dalam hal jenis protein yang menempel pada mTOR, perbedaan lokasi dalam sel dan protein yang mengalami fosforilasi. Berikut adalah perbedaannya:
1. mTORC1 termasuk mTOR, raptor, mLST8/G $\beta L$, PRAS40 dan deptor.

2. mTORC2 termasuk mTOR, rictor, mLST8/G $\beta L$, protor, deptor dan mSIN1.

Terdapat berbagai cara untuk mengaktifkan mTOR namun demikian tahap akhir dari jalur ini adalah aktivasi mTOR oleh protein-G kecil yang disebut dengan Rheb (Ras homologue enriched in brain). Tahap awal aktivasi mTOR adalah melalui 1) Growth factor seperti IGF - 1 dan insulin, 2) asam amino, 3) latihan otot, 4) $G$-protein coupled receptor (GPCR).

Aktivasi mTOR ini akan berinteraksi dengan latihan daya tahan otot yang menghasilkan kondisi AMP dan $\mathrm{NAD}^{+}$yang tinggi yang akhirnya menghambat aktivasi mTOR melalui mekanisme oleh AMPK, TSC2 dan Rheb (9). Hal ini menegaskan bahwa otot tidak akan disintesis apabila tubuh menggunakan energi yang dimilikinya untuk aktivitas lain.

Kompleks mTORC1 yang aktif akan mengaktifkan translasi melalui fosforilasi protein regulator $4 \mathrm{E}-\mathrm{BP} 1$ dan $\mathrm{p} 70 \mathrm{SK} 1$. Sehingga, mTORC1 adalah pusat dari jalur mTOR. Protein ini diaktifkan oleh latihan otot, asam amino, dan hormon dan dapat 
dihambat oleh latihan erobik. Kompleks mTORC1 aktif akan meningkatkan inisiasi translasi dan elongasi yang akan menghasilkan peningkatan sintesis protein. Apabila sintesis protein lebih tinggi daripada pemecahannya dalam waktu yang cukup akan terjadi hipertropi ${ }^{(3)}$.

\section{B. Jalur Katabolik myostatin - Smad}

Pertumbuhan otot sangat tergantung dengan mTOR sedangkan jalur myostatin - Smad adalah jalur yang menghambat pertumbuhan otot. Jadi pasangan kedua jalur ini adalah pasangan yang saling berlawanan. Pada penelitian oleh McPherron dkk (1997) pada tikus, anjing dan sapi dengan mutasi jalur myostatin - Smad terjadi pertumbuhan otot yang jauh lebih besar. Penelitian Sutrave dkk
(1990) dengan menggunakan transcriptional repressor akan mengakibatkan pertumbuhan 3 kali lipat dari normal. Pada penelitian tersebut belum jelas bagaimana myostatin dipengaruhi oleh latihan otot. Walaupun demikian, model genetik menunjukkan bahwa jalur tersebut dapat mengontrol ukuran otot. Apabila myostatin mengalami mutasi atau dihilangkan maka sel akan berada pada kondisi dimana jumlah myostatin berkurang dibandingkan keadaan saat pertumbuhannya. Pada kondisi ini akan terjadi hiperplasia dan juga hipertropi. Sedangkan apabila myostatin dihambat pada saat dewasa dengan antibodi myostatin, follistatin, hipertropi adalah efek utamanya ${ }^{(10,11)}$ Myostatin diperkirakan bekerja melalui jalur aktivasi faktor transkripsi Smad ${ }^{(11)}$.

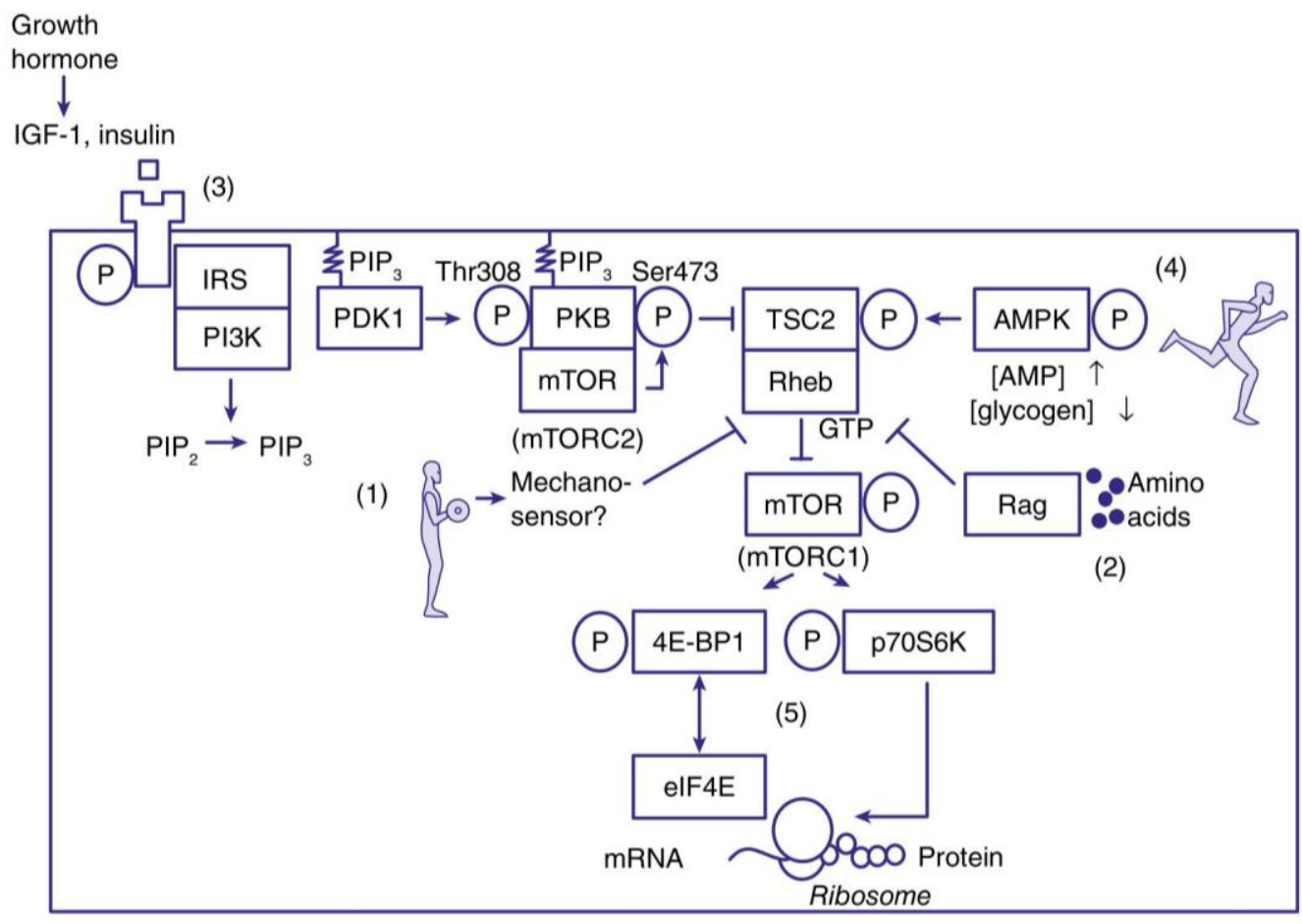

Skeletal muscle fibre

Gambar 2: Wackerhage 2014 - Molecul (2) (3)

\section{Jalur Repair oleh Sel Satelit}

Mauro menggambarkan sel satelit sebagai sel yang terjepit diantara membran otot dan basal lamina. Karena posisinya inilah diberi nama sel satelit. Sel ini terdiri dari nukleus dengan sedikit sitoplasma dan diperkirakan berfungsi 
untuk repair jaringan otot rangka ( ${ }^{12)}$. Penelitian oleh Colins (2005) memastikan bahwa sel satelit adalah sel induk sejati dan berfungsi untuk perbaikan atau repair jaringan otot saat mengalami kerusakan ${ }^{(13)}$. Dari satu sel satelit dapat diperoleh $20-80$ ribu progenitor sel untuk beberapa kali regenerasi setelah cedera (14). Sehingga, sel satelit adalah sel induk utama untuk jaringan otot, sel induk lainnya memiliki kemampuan terbatas untuk perbaikan jaringan otot.

Mekanisme molekuler yang mengatur dan perkembangan jaringan otot baru disebut dengan nama myogenesis. Proses ini tidak hanya terjadi pada masa embrional saja melainkan juga pada kondisi pertumbuhan dan cedera. Gen yang mengatur proses myogenesis disebut dengan myogenic regulatory factors (MRF). Termasuk ke dalam MRF antara lain MyoD, Myf5, Myf4(6) serta myogenin. MyoD dan Myf5 memiliki fungsi saling tergantung satu sama lain sedangkan myogenin diekspresikan pada tahap setelah MyoD dan Myf5. MyoD mampu mengubah satelit sel menjadi serabut otot, demikian juga memiliki efek yang sama terhadal sel pigmen, saraf, dan myoblast menjadi serabut otot (15). Peranan dari MRF ini adalah mengubah sel satelit menjadi sel otot. Pada keadaan sel satelit tidak aktif akan dijumpai kadar MRF yang rendah. Faktor transkripsi Pax7 memainkan peranan penting dalam proses ini, memastikan spesifikasi sel satelit. Pada kondisi tidak terstimulasi sel satelit hanya mengekspresikan $\mathrm{Pax} 7$, dan tidak mengekspresikan MyoD. Sehingga, Pax7 digunakan sebagai biomarker untuk mendeteksi satelit sel secara imunohistokimia ${ }^{(16)}$. Pada saat terjadi cedera otot, sel satelit menjadi aktif, mengakami proliferasi membentuk cluster dan bahkan mengalami diferensiasi (18). Aktivasi sel satelit terjadi saat pembebanan dan cedera menembus basal lamina menuju serabut otot (17). Aktivitasi ini ditandai dengan ekspresi MyoD dan Pax7. Bentuk diferensiasi sel satelit yang aktif adalah : a) kembali menjadi inaktif, b) bergabung dengan serabut yang mengalami hipertropi atau c) membentuk serabut baru saat terjadi cedera $\left(1^{8)}\right.$. Sel yang mengalami diferensiasi kemudian keluar dari siklus sel dan mengekspresikan myogenin yang memicu proses penyatuan (fusion). Inaktivasi sel satelit terjadi setelah cedera hilang, sel menjadi inaktif dan tidak lagi mengekpresikan MyoD.

\section{Kesimpulan}

Latihan beban adalah latihan dengan memberikan beban pada otot dimana hipertropi adalah adaptasi yang umum dijumpai. Latihan beban akan meningkatkan sintesis protein dan pemecahan protein. Keseimbangan protein yang positif diperlukan untuk terjadinya hipertropi. Aktivasi jalur mTOR adalah mekanisme utama terjadinya sintesis protein yang mendasari hipertropi. Myostatin sebagai faktor penghambat pertumbuhan otot dijumpai menurun setelah latihan beban. Sel satelit adalah sel induk pada jaringan otot yang mengekspresikan Pax 7 dan secara normal berada dalam keadaan tidak aktif. Stimulasi pertumbuhan dan cedera akan mengaktifkan sel satelit yang ditandai dengan ekspresi MyoD. Sel ini kemudian mengalami proliferasi dan diferensiasi sebagai proses regenerasi dan pemeliharaan jangka panjang otot hipertropik

\section{Daftar Pustaka}

1. Stump CS, Henriksen EJ, Wei Y, Sowers JR. The metabolic syndrome: Role of skeletal muscle metabolism. Ann Med 2006; 38(6):389-402.

2. Luzi L, editor. Cellular Physiology and Metabolism of Physical Exercise. Milano: Springer Milan; 2012.

3. Wackerhage H. Molecular exercise physiology: An introduction. London, 
New York: Routledge Taylor \& Francis Group; 2014.

4. Sale DG. Neural adaptation to resistance training. Med Sci Sports Exerc 1988; 20(5 Suppl):S135-45.

5. van Cutsem M, Duchateau J, Hainaut K. Changes in single motor unit behaviour contribute to the increase in contraction speed after dynamic training in humans. J Physiol 1998; 513 (Pt 1):295-305.

6. Bohé J, Low JFA, Wolfe RR, Rennie MJ. Rapid Report. J Physiol 2001; 532(2):575-9.

7. Phillips SM, Tipton KD, Aarsland A, Wolf SE, Wolfe RR. Mixed muscle protein synthesis and breakdown after resistance exercise in humans. American Journal of Physiology - Endocrinology and Metabolism 1997; 273(1):E99-E107. Available from: URL: http://ajpendo.physiology.org/content/aj pendo/273/1/E99.full.pdf.

8. Tipton KD, Ferrando AA, Phillips SM, Doyle D, JR, Wolfe RR. Postexercise net protein synthesis in human muscle from orally administered amino acids. Am J Physiol 1999; 276(4 Pt 1):E628-34.

9. Inoki K, Zhu T, Guan K-L. TSC2 Mediates Cellular Energy Response to Control Cell Growth and Survival. Cell 2003; 115(5):577-90.

10. Whittemore L-A, Song $\mathrm{K}$, Li X, Aghajanian J, Davies M, Girgenrath S et al. Inhibition of myostatin in adult mice increases skeletal muscle mass and strength. Biochem Biophys Res Commun 2003; 300(4):965-71.

11. Welle S, Mehta S, Burgess K. Effect of postdevelopmental myostatin depletion on myofibrillar protein metabolism. Am J Physiol Endocrinol Metab 2011; 300(6):E993-E1001.
12. MAURO A. Satellite cell of skeletal muscle fibers. J Biophys Biochem Cytol 1961; 9:493-5.

13. Collins CA, Olsen I, Zammit PS, Heslop L, Petrie A, Partridge TA et al. Stem cell function, self-renewal, and behavioral heterogeneity of cells from the adult muscle satellite cell niche. Cell 2005; 122(2):289-301.

14. Sacco A, Doyonnas R, Kraft P, Vitorovic S, Blau HM. Self-renewal and expansion of single transplanted muscle stem cells. Nature 2008; 456(7221):502-6.

15. Weintraub H, Tapscott SJ, Davis RL, Thayer MJ, Adam MA, Lassar AB et al. Activation of muscle-specific genes in pigment, nerve, fat, liver, and fibroblast cell lines by forced expression of MyoD. Proc Natl Acad Sci U S A 1989; 86(14):5434-8.

16. Seale P, Sabourin LA, Girgis-Gabardo A, Mansouri A, Gruss P, Rudnicki MA. $\operatorname{Pax} 7$ is required for the specification of myogenic satellite cells. Cell 2000; 102(6):777-86.

17. Otto A, Collins-Hooper H, Patel A, Dash PR, Patel K. Adult skeletal muscle stem cell migration is mediated by a blebbing/amoeboid mechanism. Rejuvenation Res 2011; 14(3):249-60.

18. Zammit PS, Golding JP, Nagata Y, Hudon V, Partridge TA, Beauchamp JR. Muscle satellite cells adopt divergent fates: a mechanism for self-renewal? J Cell Biol 2004; 166(3):347-57. 